\title{
INTERGENERATIONAL TRANSMISSION OF RACE: \\ PERMEABLE BOUNDARIES BETWEEN 1970 AND 2010
}

by

\author{
Carolyn A. Liebler* \\ University of Minnesota
}

and

\begin{abstract}
Marie DeRousse-Wu *
University of Minnesota
\end{abstract}

CES 12-24 September, 2012

The research program of the Center for Economic Studies (CES) produces a wide range of economic analyses to improve the statistical programs of the U.S. Census Bureau. Many of these analyses take the form of CES research papers. The papers have not undergone the review accorded Census Bureau publications and no endorsement should be inferred. Any opinions and conclusions expressed herein are those of the author(s) and do not necessarily represent the views of the U.S. Census Bureau. All results have been reviewed to ensure that no confidential information is disclosed. Republication in whole or part must be cleared with the authors.

To obtain information about the series, see www.census.gov/ces or contact C.J. Krizan, Editor, Discussion Papers, U.S. Census Bureau, Center for Economic Studies 2K130F, 4600 Silver Hill Road, Washington, DC 20233, CES.Papers.List@census.gov. 


\begin{abstract}
We study the social construction of race boundaries by investigating patterns in the race, ancestry, and Mexican origin responses provided for children of 14 types of interracial marriages using dense restricted-use data from 1970 to 2010 . Our broader purpose is to expose social processes that convert a newborn child of mixed heritage into an adult person of a particular race. We include a more diverse set of families, a longer time span, and more accurate estimates than prior research. These expansions bear fruit.Taking ancestry responses into account and studying the longer-term patterns reveals that mixed-heritage responses have been common since 1980. Expanding the types of mixed heritage and including double-minorities shows that there is substantial variation in response patterns across the 14 groups.
\end{abstract}

* We are grateful to the Minnesota Research Data Center (MnRDC) Small Grants Program for financial support. This research was conducted in the MnRDC, which receives funding from the National Science Foundation (SES-0851417). We also gratefully acknowledge support from the Minnesota Population Center, which is funded by a center grant from the National Institutes of Health (R24-HD041023). Any opinions and conclusions expressed herein are those of the authors and do not necessarily represent the views of the U.S. Census Bureau. All results have been reviewed to ensure that no confidential information is disclosed. 


\section{Introduction}

Multiracial individuals have existed for centuries but have not always been allowed to identify as such in federal censuses and surveys. A first-generation multiracial person - a person who is the child of two parents of different single $\operatorname{races}^{1}$ (Daniel 1996) - is faced with many options in terms of how to report his or her heritage (Song 2003). These options are limited by social and personal constraints that are otherwise difficult to see but that constitute important forces in the process of racial identity formation (Omi and Winant 1994). By studying the heritage that is reported by (or for) a first-generation multiracial person, scholars of the social construction of race gain leverage on past and present boundaries of race groups.

In this project, we use information provided in the census for first-generation multiracial people to study the ways in which race boundaries have changed over forty years in the United States. Our work expands upon prior research in four ways. We study the period 1970 to 2010, rather than focusing on a single year. We use dense restricted-use census and American Community Survey data (housed in the Census Bureau Research Data Centers) to gain large samples and detailed response information. We study many parent-race pairings, including seven double-minority pairings, rather than focusing on only children of interracially married whites. And we investigate the race and ancestry responses given for the children of each pairing to more thoroughly understand the complexities of individuals' identities.

Our research questions are fourfold. First, how have the parents ${ }^{2}$ in fourteen types of interracial marriages described the race(s) and ancestries (and Mexican origin, when applicable) of their children? Second, how and why is the distribution of responses different between different parent race pairs? Third, how have the distributions of responses changed over the four decades and with important changes in how the questions were asked? And fourth, what is the role of surnames in the intergenerational transmission of race?

We focus on the ways interracially married parents have identified their children, and how that has varied over time and across groups because we want to know where the race boundary 
lines are drawn and how rigid or permeable these boundaries are. For example, if we find that children of mixed $X-Y$ heritage are often reported as single race $X$, then we would conclude that the social definition of race $X$ is relatively inclusive; the boundary of race $X$ would seem fairly permeable and rather far from the center of the definition. If, on the other hand, many children of mixed $X-Y$ heritage are reported as both $X$ and $Y$ races, we could infer that the boundaries of both races are rigid and are not inclusive of people who do not fit the socially accepted definition of a race group member. Individuals and families consciously or unconsciously take these social rules into account when deciding how to racially identify a child of mixed racial heritage. A wide variation in responses given for people of similar race backgrounds would indicate that the social rules, if they exist, are not well known.

\section{Literature review and hypotheses}

Although it is now possible to report mixed racial background on official federal documents, many interracially married people report their children as a single race. Analysts have explored factors related to survey respondents providing one particular race response (as opposed to another) on their survey or census (e.g., Harris and Sim 2002). A series of quantitative analyses using data from the public use version of the 1990 census (which instructed respondents to mark ONE race) has identified predictors of which race is reported for a coresident child of an interracially married Asian (Xie and Goyette 1998), American Indian or Alaska Native (Liebler 2001, 2004), black (Campbell 2007; Roth 2005), Native Hawaiian (Kanaiaupuni and Liebler 2005), Pacific Islander (Liebler and Kanaiaupuni 2003/4), or white (Qian 2004). Some work has expanded to data from Census 2000 (Bratter 2007; Liebler 2010a, 2010b; Jones and Smith 2003), but research incorporating multiple years of data is extremely rare.

These research projects have proven important for establishing the field of study, but they have been limited by the sparse data available in the public use files. Additionally, the bulk of this research stream has used the child's (single) race as the dependent variable, not taking into 
account whether the child's ancestry reports reflect the racial background of the other parent (except Gullickson and Morning (2010)). By using the ancestry question, as well as the race of the Mexican origin parent and the Hispanic origin of Mexicans' children, we are potentially tapping into multiple layers of racial/ethnic identities and moving away from a reliance on a single, perhaps ineffective, measure of a complex reality (see Burton, Nandi, and Platt 2010 for a related discussion).

We use several terms whose meaning must be clarified. Race, ancestry, and Hispanic origin are socially-constructed categorical concepts that are tapped by three separate questions asked by the Census Bureau. A person's ancestry is expected to be a list of countries (e.g, Italy, China) or ethnic groups (e.g, Sicilian, Han) from whence their ancestors came; it is closely related to a family tree. Hispanic origin is a separate survey question for sociopolitical reasons but is conceptually parallel to ancestry in that it taps the national origins (e.g., Mexico) of the person's (Spanish speaking) ancestors. A person's race is thought to be ascribed by others and based on how they look and where their ancestors are from; race is more actively socially constructed than ancestry, and is extremely socially consequential. A person may have ancestry or Hispanic origin from several socially-defined race groups (e.g., white and Asian) and thus have claim to several races. In this research, we call this person someone with mixed heritage in order to remain agnostic about which race(s) and/or ancestries they will actually report when asked. The broader purpose of this line of research is to uncover social processes that convert a newborn child of mixed heritage into an adult person of a particular race.

Since the ancestry question was introduced in 1980 , parents have been able to identify children as having a mixed heritage. Do interracially married parents use the ancestry question along with the race question to report their children's mixed racial heritage? Do these parents increasingly report their children as having mixed heritage, now that there is increased public focus on multiracialism? Are these answers different across time and in different groups? In the remainder of this section, we discuss our four focal questions and use results from prior studies to 
formulate hypotheses related to each.

Focus on mixed heritage: We begin this research by asking: how have interracially married parents described the race(s) and ancestries of their children? This is a basic question that does not focus on differences across groups or change over time - it is simply asking whether most children who live with parents of two different races are reported as also having those two race backgrounds.

Several forms of internal and external pressures can push a person to identify as a single race. Single race identity enhances a sense of group belonging (Rockquemore and Brunsma 2002) and minimizes sense of being a "marginal man" (Park 1928; Stonequist 1937). Monoracial assumptions by communities and society as a whole (c.f. Spickard 2001) can also serve to minimize the appeal of a multiracial identity. Because of the enhanced salience of one group, children of mixed heritage who are raised by only one parent may be consciously or unconsciously socialized to primarily identify with that parent's group (Liebler 2001; Rockquemore and Laszloffy 2005). If a child of mixed heritage is reported to be monoracial, the other parent's race group experiences "ethnic attrition" (Duncan and Trejo 2011).

Despite these pressures, there is reason to believe that a majority of the children in this study will be reported as having mixed heritage. All of the children in this study are living with both of their interracially married parents, so both racial origins are likely to be salient to whoever is filling out the questionnaire. Qualitative studies of multiracial individuals have given voice to many who feel that they are a combination of both of their parents and should not be categorized as belonging entirely to one group or the other (Korgen 1998; Root 1996; Rockquemore and Brunsma 2002). Social movement organizations surrounding interracial marriages and the children of these marriages (e.g. ProjectRACE) also espouse the view that people of mixed heritage want to report their heritage as mixed; they agree with golf champion Tiger Woods that a mixed heritage requires a mixed identity. Other discussions of multiracial identity emphasize that many people reserve the rights to self-categorize and to change this self-categorization when 
contexts change (e.g., Cheng and Lively 2009; Tashiro 2012). Many of these self-categorizations involve a combination of racially-dissimilar responses. Based on these considerations, we hypothesize that children of interracially married parents will be reported as having mixed heritage, whenever and however it is possible to report it.

Group differences: Our second research question inquires about the likely variation among children from these fourteen types of interracial marriages. The groups (listed below) vary widely in their experiences and social positions, and so it is sensible to expect variation in the decisions made by these parents. We ask: how and why is the distribution of responses different between different parent race pairs?

Groups which are socially defined as non-white (e.g., Irish or Jewish) may move toward recognition as white, often using classic assimilation processes (Brodkin 1998; Gordon 1964; Haney Lopez 2006; Painter 2010; Roediger 2005; Warren and Twine 1997). At the individual level, however, whiteness can be less claimable; prior research shows the white race boundary as impermeable and an emphasis on purity within the social construct of whiteness (Lee and Bean 2004). Which individuals are considered to be white has historically been carefully guarded, both socially and legally (c.f., Haney Lopez 2006). For generations, the number of multiracial part-white people has been minimized through extensive laws about interracial marriages (see Spickard 1991). Self-identification by such individuals as white is often described negatively as "passing" and as an affront to black or minority pride (Davis 2001; Nakashima 1992; Russell, Wilson, and Hall 1992) and are among the worst fears of white supremacists (Ferber 2004). Self-identification as white by a multiracial is also associated with lower educational outcomes compared to self-identification as multiracial (Burke and Kao 2011). We hypothesize that a child with a white parent and a non-white parent will tend to not be reported as single-race white.

Blackness has been historically constructed in an opposite way - both legally and socially, a part-black person has been considered just black (Cornell 1990; Davis 2001; Jordan 1962); this race boundary has been extremely broad and permeable. In the past, categories such as 
"mulatto" indicate a part-black person's mixed heritage. These have been treated as sub-categories of the black group to such an extent that these categories were eliminated from the census to reduce redundancy. The contemporary case of President Barack Obama illustrates the continuing societal emphasis on blackness as overpowering all other heritages. If a part-black person wishes to present a not-just-black identity, the person is likely to present him or herself as multiracial rather than single-race non-black (Khanna 2011). If these processes are evident in the data from 1970 to 2010, we would see that a child with a black parent and a non-black parent will tend to be reported as single-race black, though other heritages may be reported subordinately (as ancestries). A child of a black parent is unlikely to be presented as single-race non-black. Multiracial indigenous people face different constraints and pressures than the groups discussed above. In the United States, indigenous people (American Indians, Alaska Natives, and Native Hawaiians) have political relationships with both federal and tribal governments. Both types of governments are charged with patrolling the boundaries of membership in these groups, and group members have entered the fray. Who counts as "real" is hotly contested (Garroutte 2003; Hagan 1985). Mixed-heritage members of these groups are subject to being asked for proof of their indigenous heritage, and those who cannot provide it risk social and economic consequences (e.g., see Bauerlein 2012). Because the stakes are high, we expect that American Indian, Alaska Native, and Native Hawaiian interracially married parents will tend to claim their child's indigenous heritage strongly if proof of heritage can be provided to those who question the child's identification. If this proof is not available, the parents may eschew identification with the indigenous group so as to avoid conflict and embarrassment. In other words, the race boundaries are wide (inclusive of multiple ancestries) but rigid (some claims do not pass muster). Together, these ideas lead us to the following hypothesis about families with a parent who is American Indian, Alaska Native, or Native Hawaiian: children in these groups will tend to be reported as monoracial - either wholly indigenous or not indigenous at all.

There is a countervailing pressure, however. Ironically, though not coincidentally, 
indigenous people also have an especially long history of forming interracial unions and a majority of American Indian and Native Hawaiian people are of mixed descent. Relatedly, Pacific Islanders and other people in Hawaii are famous for welcoming multiracial people and identities (Rohrer 2008; Smith 1934; Spickard 2001; Spickard and Fong 1995), including a personal "consciousness of multiplicity" (Spickard 2001:23). The community-wide conversations about such things as blood-quantum and mixed parentage may make it so that interracially married American Indian, Alaska Native, and Pacific Islander parents will tend to report their child's mixed heritage.

Increase over time: Our third research question engages the several decades under study. We ask: how have the responses changed over the four decades and with important changes in how the questions were asked? There have certainly been tremendous changes in the lived experience of race in the years between 1970 and 2010. Over this period, American conceptions of race have grown from an inflexible, biological understanding to a more nuanced and culturally-based understanding. ${ }^{3}$ Transformations in norms and attitudes are likely to be reflected in the race and ancestry responses given for the children of interracially married parents. A person who identifies as multiracial was very rare in the 1970 s and is fairly common in the twenty-first century. Mixed heritage could not be reported in the 1970 census form, but the introduction of the ancestry question in 1980 and the allowance for multiple race responses beginning in 2000 have made it possible for parents to report their child's mixed heritage in four of the five data sets we use. Because of increasing social acceptance of a nuanced conception of race, we hypothesize that mixed heritage responses will be increasingly common from 1980 to 2010 among children of interracially married parents.

Distinctive paternal surname: Our final hypothesis relates to a more everyday aspect of life in an interracial marriage: the family's name. The importance of names in both communicating and determining ethnic identity has been established in sociological research (Davies 2011; Lieberson 2000; Nakashima 2001; Waters 1990). In many American families, the wife and children take on the husband's surname and in families where the husband is passing on a name 
that is racially or ethically distinct - such as many Asian, Pacific Islander, and Mexican names the child may be ascribed a race or ethnicity that matches the name. Because of surname interpretation, we expect that, when applicable, children will tend to be racially identified as the same race as their Asian, Pacific Islander, or Mexican father.

\section{Methodology}

Data: We use restricted-use census long form data from the National Historical Census Files for 1970, 1980, 1990, 2000, and the five-year pooled 2006-2010 American Community Survey. These data are housed in the Census Bureau's Research Data Centers (RDCs). These data provide substantially more cases than the public versions of the data - the RDC files include all households enumerated with the long form and are approximately 1-in-6 samples of US households. The density of these samples is vital to our research on these small populations because it allows us to include a detailed breakdown of the child's race/ancestry/Hispanic origin responses. The RDC data also provide more detail in both the ancestry and race codes than the public use data. For example, the 1990 restricted data offers information about people who marked two races in that year, even though the census instructions requested a single race response.

Since 1960, census responses have been provided by someone in the household rather than an enumerator. ${ }^{4}$ This change was particularly important for the reporting of race because enumerators were asked to follow guidelines for the racial identification of multiracial children (over the decades variously reporting the child as the mother's race, the father's race, the first race mentioned, or the minority race). Parents reporting their child's race(s), on the other hand, have been free to choose for themselves.

Sample selection: We select our sample to include one parent who is listed as the "householder" and who is reported as married to someone listed as the "spouse." Due to census coding policies, all householder-spouse pairs in the data are male-female pairs. We include only parents who report a single race in order to minimize the unobserved variation in previous 
generations of interracial unions within the family; see Bratter (2007) for a study of intergenerational transmission of race by multiracial parents.

To maximize sample size, we include every coresident child of the householder in the data, regardless of age. ${ }^{5}$ The word "child" is indicating the family relationship, not the age of the person. In some cases, the number of children from double-minority intermarriages is still too small to generate meaningful column percentages; we omit the data from our results in these cases.

Measurement: The primary variables of interest in these data are the race response(s), ancestry response(s), and Mexican origin response(s) given for (or by) each child in these families. As noted above, we have no way of knowing who filled out the form. Given that people usually list themselves first when filling out a form, the answers given for the child are likely to be supplied by the householder (the person listed first on the form) - a parent of the child. However, it is possible that a different person filled out the form. In cases where the answers are provided by a parent or the child, the responses can be seen as a combination of the child's "internal identity" (self-perception), "expressed identity" (self-presentation), and "observed identity" (observer's interpretation) (Harris and Sim 2002).

Measuring race: The race question has changed considerably over the years 1970-2010, as shown in Table 1. In 1990 and later, the data provide information about those who reported two or more races, though multiple responses were not invited until 2000 . The availability of race response categories has also increased tremendously during this period (see Table 2). Six race responses were consistently offered throughout the time period (white, black, American Indian or Alaska Native, Chinese, Japanese, and Filipino). We also include six other groups (Asian Indian, Korean, Vietnamese, Native Hawaiian, Guamanian, and Samoan) in the analyses, as available. In order to achieve sufficient sample size, we present combined results for families with a parent who is Asian Indian, Filipino, Korean, or Vietnamese. Similarly, we present combined results for families with a parent who is Hawaiian, Guamanian, or Samoan. 


\section{Table 1:}

Census and ACS questions about Race, Ancestry, and Hispanic Origin

\section{Race Questions}

1970 4. COLOR OR RACE. Fill one circle.

1980 4. Is this person - Fill one circle.

1990 4. Race. Fill ONE circle for the race that the person considers himself/herself to

2000 6. What is this person's race? Mark $(X)$ one or more races to indicate what this person considers himself/herself to be

2006-10 6. What is this person's race? Mark $(X)$ one or more races to indicate what this person considers himself/herself to be

\section{Ancestry Questions}

$1970 \quad$ N/A

1980 14. What is this person's ancestry? If uncertain about how to report ancestry, see instruction guide. (For example: Afro-Amer., English, French, German, Honduran, Hungarian, Irish, Italian, Jamaican, Korean, Lebanese, Mexican, Nigerian, Polish, Ukrainian, Venezuelan, etc.)

1990 13. What is this person's ancestry or ethnic origin? (See instruction guide for further information.) (For example: German, Italian, Afro-Amer., Croatian, Cape Verdean, Dominican, Ecuadorean, Haitian, Cajun, French Canadian, Jamaican, Korean, Lebanese, Mexican, Nigerian, Irish, Polish, Slovak, Taiwanese, Thai,

2000 10. What is this person's ancestry or ethnic origin? (For example: Italian, Jamaican, African Am., Cambodian, Cape Verdean, Norwegian, Dominican, French Canadian, Haitian, Korean, Lebanese, Polish, Nigerian, Mexican,

2006-10 12. What is this person's ancestry or ethnic origin? (For example: Italian, Jamaican, African Am., Cambodian, Cape Verdean, Norwegian, Dominican, French Canadian, Haitian, Korean, Lebanese, Polish, Nigerian, Mexican, Taiwanese, Ukrainian, and so on.)

\section{Hispanic Origin Questions}

$1970 \quad$ N/A

1980 7. Is this person of Spanish/Hispanic origin or descent? Fill one circle.

1990 7. Is this person of Spanish/Hispanic origin? Fill ONE circle for each person.

2000 5. Is this person Spanish/Hispanic/Latino? Mark [X] the "No" box if not Spanish/Hispanic/Latino.

2006-10 5. Is Person X of Hispanic, Latino, or Spanish origin? 
Table 2:

Selected Race Response Categories Offered as Check-Boxes in Decennial Census and the American Community Survey

\begin{tabular}{|c|c|c|c|c|c|}
\hline & 1970 & 1980 & 1990 & 2000 & 2006-10 ACS \\
\hline white & $x$ & $x$ & $x$ & $x$ & $\mathrm{x}$ \\
\hline black & $x$ & $x$ & $\mathrm{x}$ & $\mathrm{x}$ & $\mathrm{x}$ \\
\hline \multicolumn{6}{|c|}{ American Indian or Alaska } \\
\hline Native & $x$ & $x$ & $\mathrm{x}$ & $x$ & $x$ \\
\hline Chinese & $x$ & $x$ & $x$ & $x$ & $x$ \\
\hline Japanese & $x$ & $x$ & $x$ & $x$ & $x$ \\
\hline \multicolumn{6}{|l|}{ "other Asian" group } \\
\hline Asian Indian & & $\mathrm{x}$ & $x$ & $x$ & $x$ \\
\hline Filipino & $x$ & $x$ & $x$ & $x$ & $x$ \\
\hline Korean & $x$ & $x$ & $x$ & $x$ & $x$ \\
\hline Vietnamese & & $x$ & $x$ & $x$ & $x$ \\
\hline \multicolumn{6}{|c|}{ "Pacific Islander" group } \\
\hline Hawaiian & $x$ & $x$ & $\mathrm{x}$ & $\mathrm{x}$ & $x$ \\
\hline Guamanian & & & $x$ & $\mathrm{x}$ & $x$ \\
\hline Samoan & & & $x$ & $x$ & $x$ \\
\hline "other race" & $x$ & $\mathrm{x}$ & $x$ & $x$ & $x$ \\
\hline
\end{tabular}


Measuring Mexican origin: Since 1980, the censuses have included a question assessing each person's Hispanic origin (see Table 1 for wording). The response option of "Mexican" has been offered in some form each year since then. In the general population of Mexican origin people, about half report a single race of white, and about half mark the "other race" box that ends each race question. We agree with Brown, Hitlin, and Elder (2007; Hitlin, Brown, and Elder 2007) that the race responses given by Hispanics are worthy of analytic attention. Non-Hispanic responses among people of Latin American heritage are fairly common (Duncan and Trejo 2011; Emeka and Vallejo 2011). In families with an interracially married parent of Mexican origin, we take into account the Mexican and/or Hispanic origin responses of parents and children.

Measuring intermarriage: We study children of fourteen types of interracial marriages between single-race parents. Seven of the race group pairs involve a white parent and seven involve a black parent. Inclusion of double-minority families is unfortunately rare in prior research and has been cited as an important avenue for expansion of knowledge (Hall and Turner 2001). Thus, the information we provide about the identification of these double-minority children represents an important contribution of this study. The specific intermarriage groups in our study are listed in Table 3.

Most respondents to the 1970 census were self-enumerated, but those who did not respond to the initial mailed questionnaire were followed up by in-person enumerators and/or phone calls. In these cases, the race of the respondent was assumed to be the race of everyone in the household (U.S. Bureau of the Census 1976) and thus some intermarriages were not coded as such in 1970.

Measuring ancestry: The census of 1970 did not ask about ancestry or ethnic origin. In 1980, the Census Bureau began collecting ancestry data using an open-ended question asking "What is this person's ancestry or ethnic origin?" and coded the first two responses (with a few triple-ancestry exceptions in 1980). This question was asked in each census since 1980 and is also in the American Community Survey; see Table 1 for the exact wording. We coded a child as 
Table 3:

Fourteen Types of Intermarriages between Single-Race People

\begin{tabular}{|c|c|c|}
\hline & $\begin{array}{l}\text { race of one } \\
\text { parent }\end{array}$ & race of the other parent \\
\hline 1) & white & black \\
\hline 2) & white & American Indian or Alaska Native ("American Indian" or AIAN) \\
\hline 3) & white & Chinese \\
\hline 4) & white & Japanese \\
\hline 5) & white & Asian Indian, Filipino, Korean, or Vietnamese ("other Asian" or AFKV) \\
\hline 6) & white & Hawaiian, Guamanian, or Samoan ("Pacific Islander" or PI) \\
\hline 7) & white & "other race" and Mexican origin \\
\hline 8) & black & American Indian or Alaska Native ("American Indian" or AIAN) \\
\hline 9) & black & Chinese \\
\hline 10) & black & Japanese \\
\hline 11) & black & Asian Indian, Filipino, Korean, or Vietnamese ("other Asian" or AFKV) \\
\hline 12) & black & Hawaiian, Guamanian, or Samoan ("Pacific Islander" or PI) \\
\hline 13) & black & "other race" and Mexican Hispanic origin \\
\hline 14) & black & white race and Mexican Hispanic origin \\
\hline
\end{tabular}

Note: Mexican origin was assessed in a separate question which asked whether the respondent is Spanish/Hispanic/Latino. 
having a certain ancestry if that ancestry was included as either of the two coded entries. Parents' ancestry responses were not taken into account. To decide whether an ancestry report suggests a particular racial heritage, we follow the Bureau of Labor Statistics and prior research (see Goldstein and Morning 2000, 2002; Gullickson and Morning 2010).

Measuring the child's reported heritage: The 1970 census did not include the ancestry question, the Hispanic origin question, or the ability to mark multiple races. The possible ways to report the child's combined race, ancestry, and Hispanic origin ${ }^{6}$ has varied over the years since then. The primary variable is presented as a column percent of these options. Other responses were possible in the data, but were too rare to include in the analyses. Of note is the rarity of reporting a child as Asian or Pacific Islander race with black ancestry in 2000 . Note that the data support a particularly large number of heritage responses for children who have a non-Hispanic white parent married to a Mexican origin parent who marked "other race."

\section{Results}

In Table 4, we show the distribution of race/ancestry/Hispanic origin responses provided for children who have a white parent married to a non-white parent. ${ }^{7}$ This table provides three columns per year of data. The first column shows the distribution of responses for all children (given as column percents), by parent races. The second column shows the responses given only for children whose mother reported single-race white and whose father listed the non-white race. The third column gives the response distribution for the remainder of the children - those with a white father. The first column (focusing on all children in the group) provides information relevant to most of the hypotheses and we re-present this information in stacked bar graphs in Figure 1. We present parallel information for the part-black families in Table 5 and Figure 2.

Our research questions center on how children of interracially married parents are identified in data covering 40 years. With the information presented in Tables 4 and 5, we can address our hypotheses. 
Table 4:

Child's Race and Ancestry in Families with Interracially Married Single-Race Householder \& Spouse:

Seven types of families with a white parent and a non-white parent in five data sets

\begin{tabular}{|c|c|c|c|c|c|c|c|c|c|c|c|c|c|c|c|}
\hline \multirow[b]{2}{*}{$\begin{array}{l}\text { Race of non-white parent } \\
\text { racelancestry of child } \\
\text { (column \%) }\end{array}$} & \multicolumn{3}{|c|}{1970} & \multicolumn{3}{|c|}{1980} & \multicolumn{3}{|c|}{1990} & \multicolumn{3}{|c|}{2000} & \multicolumn{3}{|c|}{ 2006-10 ACS } \\
\hline & $\begin{array}{c}\text { all } \\
\text { kids }\end{array}$ & $\begin{array}{l}\text { mom } \\
\text { is } \\
\text { white }\end{array}$ & $\begin{array}{l}\text { dad } \\
\text { is } \\
\text { white }\end{array}$ & $\begin{array}{c}\text { all } \\
\text { kids }\end{array}$ & $\begin{array}{l}\text { mom } \\
\text { is } \\
\text { white }\end{array}$ & $\begin{array}{l}\text { dad } \\
\text { is } \\
\text { white }\end{array}$ & $\begin{array}{c}\text { all } \\
\text { kids }\end{array}$ & $\begin{array}{l}\text { mom } \\
\text { is } \\
\text { white }\end{array}$ & $\begin{array}{l}\text { dad } \\
\text { is } \\
\text { white }\end{array}$ & $\begin{array}{c}\text { all } \\
\text { kids }\end{array}$ & $\begin{array}{l}\text { mom } \\
\text { is } \\
\text { white }\end{array}$ & $\begin{array}{l}\text { dad } \\
\text { is } \\
\text { white }\end{array}$ & $\begin{array}{c}\text { all } \\
\text { kids }\end{array}$ & $\begin{array}{l}\text { mom } \\
\text { is } \\
\text { white }\end{array}$ & $\begin{array}{l}\text { dad } \\
\text { is } \\
\text { white }\end{array}$ \\
\hline \multicolumn{16}{|l|}{ Black } \\
\hline W race, no black anc & 34 & 25 & 53 & 24 & 25 & 20 & 17 & 16 & 21 & 16 & 13 & 25 & 16 & 16 & 16 \\
\hline$W$ race $\&$ black anc & -- & -- & -- & 8 & 9 & 5 & 7 & 8 & 6 & 2 & 1 & 2 & 2 & 2 & 2 \\
\hline$W \&$ black races & -- & -- & -- & -- & -- & -- & 22 & 23 & 18 & 51 & 53 & 44 & 53 & 55 & 48 \\
\hline black race \& W anc & -- & -- & -- & 25 & 27 & 17 & 16 & 17 & 15 & 5 & 5 & 4 & 5 & 5 & 4 \\
\hline black race, no $W$ anc & 66 & 75 & 47 & 43 & 38 & 58 & 37 & 36 & 41 & 27 & 27 & 25 & 24 & 22 & 29 \\
\hline \multicolumn{16}{|c|}{ American Indian or Alaska Native } \\
\hline W race, no AIAN anc & 57 & 50 & 62 & 31 & 35 & 27 & 29 & 29 & 29 & 27 & 27 & 26 & 29 & 33 & 25 \\
\hline$W$ race \& AIAN anc & -- & -- & -- & 23 & 24 & 23 & 24 & 25 & 23 & 10 & 11 & 10 & 12 & 12 & 13 \\
\hline$W \& A I A N$ races & -- & -- & -- & -- & -- & -- & 0 & 0 & 0 & 16 & 16 & 17 & 4 & 4 & 4 \\
\hline AIAN race \& $W$ anc & -- & -- & -- & 21 & 18 & 23 & 16 & 16 & 17 & 10 & 9 & 10 & 11 & 11 & 11 \\
\hline AIAN race, no $W$ anc & 43 & 50 & 38 & 25 & 23 & 27 & 31 & 30 & 31 & 37 & 37 & 37 & 43 & 39 & 47 \\
\hline \multicolumn{16}{|l|}{ Chinese } \\
\hline W race, no Chinese anc & 58 & 37 & 82 & 25 & 23 & 25 & 14 & 12 & 15 & 10 & 7 & 12 & 7 & 8 & 7 \\
\hline$W$ race \& Chinese anc & -- & -- & -- & 35 & 29 & 39 & 30 & 24 & 35 & 11 & 9 & 12 & 7 & 6 & 8 \\
\hline W \& Chinese races & -- & -- & -- & -- & -- & -- & 12 & 11 & 13 & 63 & 62 & 64 & 68 & 67 & 69 \\
\hline Chinese race $\& W$ anc & -- & -- & -- & 18 & 22 & 15 & 18 & 22 & 15 & 4 & 5 & 4 & 3 & 4 & 2 \\
\hline Chinese race, no $\mathrm{W}$ anc & 42 & 63 & 18 & 23 & 26 & 20 & 26 & 31 & 22 & 12 & 18 & 9 & 14 & 15 & 14 \\
\hline \multicolumn{16}{|l|}{ Japanese } \\
\hline W race, no Japanese anc & 81 & 42 & 89 & 22 & 24 & 22 & 15 & 13 & 16 & 11 & 9 & 12 & 9 & 12 & 7 \\
\hline$W$ race \& Japanese anc & -- & -- & -- & 43 & 30 & 46 & 36 & 30 & 39 & 13 & 10 & 14 & 9 & 7 & 10 \\
\hline W \& Japanese races & -- & -- & -- & -- & -- & -- & 8 & 7 & 9 & 60 & 59 & 60 & 67 & 63 & 69 \\
\hline Japanese race \& W anc & -- & -- & -- & 17 & 26 & 14 & 18 & 21 & 17 & 4 & 6 & 3 & 3 & 5 & 3 \\
\hline $\begin{array}{l}\text { Japanese race, no W anc } \\
\text { continued... }\end{array}$ & 19 & 58 & 11 & 18 & 20 & 18 & 23 & 29 & 20 & 12 & 16 & 10 & 12 & 13 & 11 \\
\hline
\end{tabular}


Table 4, continued:

Child's Race and Ancestry in Families with Interracially Married Single-Race Householder \& Spouse:

Seven types of families with a white parent and a non-white parent in five data sets

\begin{tabular}{|c|c|c|c|c|c|c|c|c|c|c|c|c|c|c|c|}
\hline \multirow[b]{2}{*}{$\begin{array}{l}\text { Race of non-white parent } \\
\text { race/ancestry of child } \\
\text { (column \%) }\end{array}$} & \multicolumn{3}{|c|}{1970} & \multicolumn{3}{|c|}{1980} & \multicolumn{3}{|c|}{1990} & \multicolumn{3}{|c|}{2000} & \multicolumn{3}{|c|}{ 2006-10 ACS } \\
\hline & $\begin{array}{c}\text { all } \\
\text { kids }\end{array}$ & $\begin{array}{l}\text { mom } \\
\text { is } \\
\text { white }\end{array}$ & $\begin{array}{c}\text { dad } \\
\text { is } \\
\text { white }\end{array}$ & $\begin{array}{c}\text { all } \\
\text { kids }\end{array}$ & $\begin{array}{l}\text { mom } \\
\text { is } \\
\text { white }\end{array}$ & $\begin{array}{l}\text { dad } \\
\text { is } \\
\text { white }\end{array}$ & $\begin{array}{c}\text { all } \\
\text { kids }\end{array}$ & $\begin{array}{l}\text { mom } \\
\text { is } \\
\text { white }\end{array}$ & $\begin{array}{l}\text { dad } \\
\text { is } \\
\text { white }\end{array}$ & $\begin{array}{c}\text { all } \\
\text { kids }\end{array}$ & $\begin{array}{l}\text { mom } \\
\text { is } \\
\text { white }\end{array}$ & $\begin{array}{l}\text { dad } \\
\text { is } \\
\text { white }\end{array}$ & $\begin{array}{c}\text { all } \\
\text { kids }\end{array}$ & $\begin{array}{l}\text { mom } \\
\text { is } \\
\text { white }\end{array}$ & $\begin{array}{l}\text { dad } \\
\text { is } \\
\text { white }\end{array}$ \\
\hline \multicolumn{16}{|c|}{ Asian Indian, Filipino, Korean, or Vietnamese (AFKV) } \\
\hline W race, no AFKV anc & 67 & 46 & 85 & 28 & 29 & 28 & 42 & 43 & 42 & 17 & 17 & 17 & 13 & 15 & 12 \\
\hline$W$ race \& $A F K V$ anc & -- & -- & -- & 39 & 38 & 40 & 18 & 13 & 19 & 15 & 11 & 16 & 11 & 10 & 12 \\
\hline$W \& A F K V$ races & -- & -- & -- & -- & -- & -- & 4 & 4 & 4 & 51 & 50 & 51 & 58 & 57 & 59 \\
\hline AFKV race \& $W$ anc & -- & -- & -- & 10 & 13 & 9 & 11 & 13 & 10 & 3 & 4 & 3 & 3 & 4 & 3 \\
\hline AFKV race, no $W$ anc & 33 & 54 & 16 & 22 & 20 & 23 & 25 & 26 & 25 & 14 & 18 & 13 & 15 & 14 & 15 \\
\hline \multicolumn{16}{|c|}{ Hawaiian, Guamanian, or Samoan (Pacific Islander or PI) } \\
\hline W race, no $P I$ anc & 63 & 39 & 81 & 27 & 27 & 28 & 21 & 19 & 23 & 21 & 19 & 24 & 18 & 18 & 18 \\
\hline$W$ race $\& P I$ anc & -- & -- & -- & 26 & 27 & 26 & 28 & 28 & 28 & 9 & 8 & 11 & 12 & 12 & 11 \\
\hline$W \& P I$ races & -- & -- & -- & -- & -- & -- & 2 & 2 & 2 & 40 & 41 & 39 & 43 & 44 & 41 \\
\hline$P I$ race $\& W$ anc & -- & -- & -- & 21 & 22 & 21 & 17 & 17 & 17 & 6 & 6 & 6 & 6 & 5 & 7 \\
\hline$P I$ race, no $W$ anc & 37 & 61 & 19 & 25 & 25 & 25 & 32 & 34 & 30 & 24 & 26 & 22 & 22 & 21 & 23 \\
\hline \multicolumn{16}{|c|}{ "Other" race, Mexican Hispanic Origin (white spouse must be non-Hispanic) } \\
\hline W race, no $M$ anc, not $H$ & -- & -- & -- & 15 & 17 & 12 & 16 & 17 & 13 & 14 & 12 & 18 & 14 & 14 & 13 \\
\hline$W$ race $\& M$ anc, not $H$ & -- & -- & -- & 9 & 7 & 12 & 22 & 19 & 27 & 9 & 6 & 13 & 6 & 3 & 9 \\
\hline$O \& W$ races, not Hispanic & -- & -- & -- & -- & -- & -- & -- & -- & -- & 2 & 1 & 2 & 2 & 1 & 2 \\
\hline W race, Hispanic origin & -- & -- & -- & 29 & 27 & 32 & 42 & 42 & 41 & 17 & 17 & 17 & 18 & 17 & 18 \\
\hline O race \& W race, Hispanic & -- & -- & -- & -- & -- & -- & -- & -- & -- & 21 & 21 & 21 & 28 & 29 & 26 \\
\hline$O$ race $\& W$ anc, Hispanic & -- & -- & -- & 18 & 20 & 14 & 7 & 8 & 5 & 7 & 7 & 6 & 8 & 9 & 7 \\
\hline O race, no $W$ anc, Hispanic & -- & -- & -- & 30 & 29 & 30 & 13 & 14 & 13 & 30 & 35 & 23 & 26 & 26 & 26 \\
\hline
\end{tabular}

Note: Column percents represent only answers listed. Other answers are rare and are not included in these results. Ancestry was first asked in 1980 and multiple race responses were first allowed in 2000 but some codes appear in the 1990 restricted-use data; see the ICPSR restricted use data codebook for details. Due to rounding, column percents may not add to 100 . See text for further information.

* = Low sample size.

$--=$ Structural zero.

$X=$ results have not yet been released 


\section{Figure 1:}

Child's Race and Ancestry in Families with Interracially Married Single-Race Householder \& Spouse: Seven types of families with a white parent and a non-white parent in five data sets

\begin{tabular}{|c|c|c|c|c|c|c|}
\hline $100 \%$ & & & & & & \\
\hline $75 \%$ & & & & & & $\square$ white race, no black ancestry \\
\hline $50 \%$ & & & $B D$ & BO & 871 & $\square$ white race \& black ancestry \\
\hline $50 \%$ & & & & & & $\nabla$ white \& black races \\
\hline $25 \%$ & & & & & & 口black race \& white ancestry \\
\hline $0 \%$ & 1970 & 1980 & 1990 & 2000 & 2006-2010 ACS & black race, no white ancestry \\
\hline $100 \%$ & & & & & & \\
\hline $75 \%$ & & & & & & 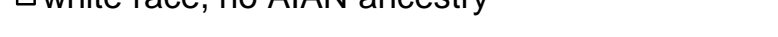 \\
\hline $50 \%$ & & & & $D 77$ & & 口white race \& AIAN ancestry \\
\hline $50 \%$ & & & & & $\infty$ & white \& American Indian or Alaska Native races \\
\hline $25 \%$ & & & & & & $\square$ AIAN race \& white ancestry \\
\hline $0 \%$ & 1970 & 1980 & 1990 & 2000 & 2006-2010 ACS & -AIAN race, no white ancestry \\
\hline $100 \%$ & & & & & & $\square$ white race, no Chinese ancestry \\
\hline $75 \%$ & & & & 87 & 87 & $\square$ white race \& Chinese ancestry \\
\hline $50 \%$ & & & $Z 7 Z$ & 17 & & Ewhite \& Chinese races \\
\hline $25 \%$ & & & & & & $\square$ Chinese race \& white ancestry \\
\hline $0 \%$ & 1970 & 1980 & 1990 & 2000 & 2006-2010 ACS & - Chinese race, no white ancestry \\
\hline $100 \%$ & & & & & & Пuxbito race no lananoco ancectry \\
\hline $75 \%$ & & & & & 877 & 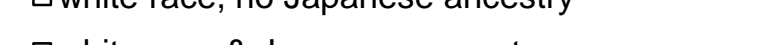 \\
\hline $50 \%$ & & & & 117 & 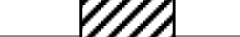 & whime race \& Japaniese ancestry \\
\hline $25 \%$ & & & 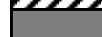 & & & awhite \& Japanese races \\
\hline $0 \%$ & & & & & & $\square$ Japanese race \& white ancestry \\
\hline & 1970 & 1980 & 1990 & 2000 & 2006-2010 ACS & -Japanese race, no white ancestry \\
\hline
\end{tabular}

continued... 
Figure 1, continued:

Child's Race and Ancestry in Families with Interracially Married Single-Race Householder \& Spouse: Seven types of families with a white parent and a non-white parent in five data sets

\begin{tabular}{|c|c|c|c|c|c|c|}
\hline \multicolumn{6}{|l|}{$100 \%$} & \multirow{4}{*}{$\begin{array}{l}\square \text { white race, no AFKV ancestry } \\
\square \text { white race \& AFKV ancestry } \\
\square \text { white \& Asian Ind., Filipino, Korean or Viet. races }\end{array}$} \\
\hline $75 \%$ & & & & \multirow{3}{*}{1717} & \multirow{3}{*}{$1 \%$} & \\
\hline $50 \%$ & & & & & & \\
\hline $25 \%$ & & & & & & \\
\hline $0 \%$ & 1970 & 1980 & 1990 & 2000 & 2006-2010 ACS & -AFKV race, no white ancestry \\
\hline \multicolumn{6}{|l|}{$100 \%$} & \multirow{5}{*}{ a white \& Hawaiian, Guam., or Samoan (PI) races } \\
\hline $75 \%$ & & & & 777 & & \\
\hline $50 \%$ & & & & & & \\
\hline $25 \%$ & & & & & & \\
\hline $0 \%$ & 1970 & 1980 & 1990 & 2000 & 2006-2010 ACS & \\
\hline \multicolumn{6}{|l|}{$100 \%$} & \multirow{7}{*}{$\begin{array}{l}\text { 口 "other" race, no white ancestry, Hispanic origin } \\
\square \text { "other" race \& white ancestry, Hispanic origin } \\
\square \text { "other" \& white races, Hispanic origin } \\
\square \text { white race, Hispanic origin } \\
\square \text { "other" \& white races, not Hispanic } \\
\square \text { white race \& Mexican ancestry, not Hispanic } \\
\square \text { white race, no Mexican ancestry, not Hispanic }\end{array}$} \\
\hline $75 \%$ & Hisp. Q & & 77 & & & \\
\hline $50 \%$ & $\begin{array}{l}\text { was } \\
\text { not }\end{array}$ & 777 & & & & \\
\hline $25 \%$ & & 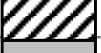 & & 117 & 17 & \\
\hline \multirow{3}{*}{$0 \%$} & & & & & & \\
\hline & 1970 & 1980 & 1990 & 2000 & 2006-2010 ACS & \\
\hline & & & & & & \\
\hline
\end{tabular}

Note: See Table 4 for a numeric version of this information. 
Table 5:

Child's Race and Ancestry in Families with Interracially Married Single-Race Householder \& Spouse:

Seven types of families with a black parent and a non-black parent in five data sets

\begin{tabular}{|c|c|c|c|c|c|c|c|c|c|c|c|c|c|c|c|}
\hline \multirow[b]{2}{*}{$\begin{array}{l}\text { Race of non-black parent } \\
\text { race/ancestry of child } \\
\text { (column \%) }\end{array}$} & \multicolumn{3}{|c|}{1970} & \multicolumn{3}{|c|}{1980} & \multicolumn{3}{|c|}{1990} & \multicolumn{3}{|c|}{2000} & \multicolumn{3}{|c|}{ 2006-10 ACS } \\
\hline & $\begin{array}{c}\text { all } \\
\text { kids }\end{array}$ & $\begin{array}{l}\text { mom } \\
\text { is } \\
\text { black }\end{array}$ & $\begin{array}{l}\text { dad } \\
\text { is } \\
\text { black }\end{array}$ & $\begin{array}{l}\text { all } \\
\text { kids }\end{array}$ & $\begin{array}{l}\text { mom } \\
\text { is } \\
\text { black }\end{array}$ & $\begin{array}{l}\text { dad } \\
\text { is } \\
\text { black }\end{array}$ & $\begin{array}{l}\text { all } \\
\text { kids }\end{array}$ & $\begin{array}{l}\text { mom } \\
\text { is } \\
\text { black }\end{array}$ & $\begin{array}{l}\text { dad } \\
\text { is } \\
\text { black }\end{array}$ & $\begin{array}{c}\text { all } \\
\text { kids }\end{array}$ & $\begin{array}{l}\text { mom } \\
\text { is } \\
\text { black }\end{array}$ & $\begin{array}{l}\text { dad } \\
\text { is } \\
\text { black }\end{array}$ & $\begin{array}{c}\text { all } \\
\text { kids }\end{array}$ & $\begin{array}{l}\text { mom } \\
\text { is } \\
\text { black }\end{array}$ & $\begin{array}{l}\text { dad } \\
\text { is } \\
\text { black }\end{array}$ \\
\hline \multicolumn{16}{|c|}{ American Indian or Alaska Native } \\
\hline$B$ race, no AIAN anc & 78 & 67 & 83 & 44 & 50 & 41 & 48 & 61 & 42 & 49 & 63 & 41 & 48 & * & * \\
\hline$B$ race \& AIAN anc & -- & -- & -- & 20 & 20 & 19 & 19 & 15 & 21 & 4 & 3 & 5 & 7 & * & * \\
\hline$B \& A I A N$ races & -- & -- & -- & -- & -- & -- & 2 & 3 & 2 & 26 & 14 & 32 & 10 & * & * \\
\hline AIAN race \& $B$ anc & -- & -- & -- & 14 & 10 & 16 & 12 & 7 & 14 & 3 & 3 & 2 & 6 & * & * \\
\hline AIAN race, no $B$ anc & 22 & 33 & 17 & 23 & 20 & 24 & 19 & 15 & 21 & 19 & 17 & 20 & 28 & * & * \\
\hline \multicolumn{16}{|l|}{ Chinese } \\
\hline$B$ race, no Chinese anc & 71 & * & * & 36 & 42 & 33 & 37 & * & * & 22 & * & * & 22 & * & * \\
\hline$B$ race \& Chinese anc & -- & -- & -- & 30 & 18 & 36 & 18 & * & * & 9 & * & * & 10 & * & * \\
\hline$B \&$ Chinese races & -- & -- & -- & -- & -- & -- & 11 & * & * & 56 & * & * & 55 & * & * \\
\hline Chinese race \& $B$ anc & -- & -- & -- & 16 & 18 & 15 & 10 & * & * & * & * & * & * & * & * \\
\hline Chinese race, no $B$ anc & 29 & * & * & 18 & 22 & 16 & 24 & * & * & 13 & * & * & 13 & * & * \\
\hline \multicolumn{16}{|l|}{ Japanese } \\
\hline$B$ race, no Japanese anc & 90 & * & * & 42 & * & * & 33 & * & * & 16 & * & * & 14 & * & * \\
\hline$B$ race \& Japanese anc & -- & -- & -- & 42 & * & * & 29 & * & * & 9 & * & * & 12 & * & * \\
\hline$B$ \& Japanese races & -- & -- & -- & -- & -- & -- & 13 & * & * & 68 & * & * & 69 & * & * \\
\hline Japanese race \& B anc & -- & -- & -- & 10 & * & * & 15 & * & * & * & * & * & * & * & * \\
\hline Japanese race, no B anc & 10 & * & * & 7 & * & * & 10 & * & * & 7 & * & * & 5 & * & * \\
\hline \multicolumn{16}{|c|}{ Asian Indian, Filipino, Korean, or Vietnamese (AFKV) } \\
\hline$B$ race, no $A F K V$ anc & 83 & 46 & 89 & 36 & 50 & 34 & 54 & * & * & 29 & 39 & 27 & 19 & 26 & 18 \\
\hline$B$ race \& $A F K V$ anc & -- & -- & -- & 34 & 16 & 37 & 11 & * & * & 11 & 7 & 11 & 9 & 5 & 10 \\
\hline$B \& A F K V$ races & -- & -- & -- & -- & -- & -- & 5 & * & * & 51 & 33 & 54 & 55 & 51 & 56 \\
\hline AFKV race \& $B$ anc & -- & -- & -- & 11 & 9 & 11 & 12 & * & * & * & * & * & 3 & 4 & 3 \\
\hline $\begin{array}{l}\text { AFKV race, no B anc } \\
\text { continued... }\end{array}$ & 17 & 54 & 11 & 20 & 26 & 19 & 17 & * & * & 9 & 20 & 7 & 13 & 14 & 13 \\
\hline
\end{tabular}


Table 5, continued:

Child's Race and Ancestry in Families with Interracially Married Single-Race Householder \& Spouse:

Seven types of families with a black parent and a non-black parent in five data sets

\begin{tabular}{|c|c|c|c|c|c|c|c|c|c|c|c|c|c|c|c|}
\hline \multirow[b]{2}{*}{$\begin{array}{l}\text { Race of non-black parent } \\
\text { race/ancestry of child } \\
\text { (column \%) }\end{array}$} & \multicolumn{3}{|c|}{1970} & \multicolumn{3}{|c|}{1980} & \multicolumn{3}{|c|}{1990} & \multicolumn{3}{|c|}{2000} & \multicolumn{3}{|c|}{ 2006-10 ACS } \\
\hline & $\begin{array}{c}\text { all } \\
\text { kids }\end{array}$ & $\begin{array}{l}\text { mom } \\
\text { is } \\
\text { black }\end{array}$ & $\begin{array}{l}\text { dad } \\
\text { is } \\
\text { black }\end{array}$ & $\begin{array}{c}\text { all } \\
\text { kids }\end{array}$ & $\begin{array}{l}\text { mom } \\
\text { is } \\
\text { black }\end{array}$ & $\begin{array}{l}\text { dad } \\
\text { is } \\
\text { black }\end{array}$ & $\begin{array}{c}\text { all } \\
\text { kids }\end{array}$ & $\begin{array}{l}\text { mom } \\
\text { is } \\
\text { black }\end{array}$ & $\begin{array}{l}\text { dad } \\
\text { is } \\
\text { black }\end{array}$ & $\begin{array}{c}\text { all } \\
\text { kids }\end{array}$ & $\begin{array}{l}\text { mom } \\
\text { is } \\
\text { black }\end{array}$ & $\begin{array}{l}\text { dad } \\
\text { is } \\
\text { black }\end{array}$ & $\begin{array}{c}\text { all } \\
\text { kids }\end{array}$ & $\begin{array}{l}\text { mom } \\
\text { is } \\
\text { black }\end{array}$ & $\begin{array}{l}\text { dad } \\
\text { is } \\
\text { black }\end{array}$ \\
\hline \multicolumn{16}{|c|}{ Hawaiian, Guamanian, or Samoan (Pacific Islander or PI) } \\
\hline$B$ race, no $P I$ anc & 84 & * & * & 66 & * & * & 37 & * & * & 29 & * & * & 27 & * & * \\
\hline$B$ race $\& P I$ anc & -- & -- & -- & 12 & * & * & 21 & * & * & 6 & * & * & 5 & * & * \\
\hline$B \& P I$ race & -- & -- & -- & -- & -- & -- & 5 & * & * & 52 & * & * & 47 & * & * \\
\hline$P I$ race $\& B$ anc & -- & -- & -- & 10 & * & * & 15 & * & * & * & * & * & 7 & * & * \\
\hline PI race, no $B$ anc & 16 & * & * & 12 & * & * & 22 & * & * & 12 & * & * & 13 & * & * \\
\hline \multicolumn{16}{|c|}{ "Other" race and Mexican Hispanic Origin (black spouse must be non-Hispanic ) } \\
\hline B race, not Hispanic & -- & -- & -- & 30 & 42 & 28 & 28 & 23 & 33 & 31 & 28 & 32 & 21 & * & * \\
\hline$O \& B$ races, not Hispanic & -- & -- & -- & -- & -- & -- & -- & -- & -- & 4 & 2 & 5 & 3 & * & * \\
\hline$B$ race, Hispanic origin & -- & -- & -- & 37 & 30 & 38 & 45 & 48 & 40 & 18 & 11 & 20 & 21 & * & * \\
\hline O \& B races, Hispanic & -- & -- & -- & -- & -- & -- & -- & -- & -- & 31 & 28 & 32 & 38 & * & * \\
\hline O race, Hispanic & -- & -- & -- & 33 & 28 & 34 & 28 & 29 & 26 & 16 & 31 & 12 & 17 & * & * \\
\hline \multicolumn{16}{|c|}{ White race and Mexican Hispanic Origin (black spouse must be non-Hispanic ) } \\
\hline$B$ race, not Hispanic & -- & -- & -- & 28 & * & * & 31 & 37 & 27 & 31 & 24 & 33 & 20 & 20 & 19 \\
\hline$W \& B$ races, not Hispanic & -- & -- & -- & -- & -- & -- & -- & -- & -- & 6 & 7 & 5 & 5 & 4 & 5 \\
\hline$B$ race, Hispanic origin & -- & -- & -- & 36 & * & * & 47 & 40 & 52 & 25 & 22 & 25 & 20 & 26 & 18 \\
\hline$W \& B$ races, Hispanic & -- & -- & -- & -- & -- & -- & -- & -- & -- & 17 & 14 & 18 & 31 & 28 & 32 \\
\hline W race, Hispanic & -- & -- & -- & 36 & * & * & 22 & 23 & 21 & 22 & 32 & 19 & 25 & 21 & 25 \\
\hline
\end{tabular}

Note: Column percents represent only answers listed. Other answers are rare and are not included in these results. Ancestry was first asked in 1980 and multiple race responses were first allowed in 2000 but some codes appear in the 1990 restricted-use data; see the ICPSR restricted use data codebook for details. Due to rounding, column percents may not add to 100 . See text for further information.

* = Low sample size. When applicable, column percents were calculated without this response option.

-- = Structural zero. 


\section{Figure 2:}

Child's Race and Ancestry in Families with Interracially Married Single-Race Householder \& Spouse: Seven types of families with a black parent and a non-black parent in five data sets

\begin{tabular}{|c|c|c|c|c|c|c|}
\hline \multicolumn{6}{|l|}{$100 \%$} & \multirow{5}{*}{$\begin{array}{l}\square \text { black race, no AIAN ancestry } \\
\square \text { black race \& AIAN ancestry } \\
\square \text { black \& American Indian or Alaska Native races } \\
\square \text { AIAN race \& black ancestry } \\
\square \text { AIAN race, no black ancestry }\end{array}$} \\
\hline $75 \%$ & & & & \multirow{3}{*}{87} & \multirow{2}{*}{272} & \\
\hline $50 \%$ & & & & & & \\
\hline \multicolumn{5}{|l|}{$25 \%$} & & \\
\hline \multicolumn{2}{|r|}{1970} & 1980 & 1990 & 2000 & 2006-2010 ACS & \\
\hline \multicolumn{6}{|l|}{$100 \%$} & \multirow{5}{*}{$\begin{array}{l}\square \text { black race, no Chinese ancestry } \\
\square \text { black race \& Chinese ancestry } \\
\square \text { black \& Chinese races } \\
\square \text { Chinese race \& black ancestry } \\
\square \text { Chinese race, no black ancestry }\end{array}$} \\
\hline $75 \%$ & & & & & 817 & \\
\hline $50 \%$ & & & 270 & 817 & 8 & \\
\hline $25 \%$ & & & & & & \\
\hline $0 \%$ & 1970 & 1980 & 1990 & 2000 & 2006-2010 ACS & \\
\hline \multirow{5}{*}{$\begin{array}{r}100 \% \\
75 \% \\
50 \% \\
25 \% \\
0 \%\end{array}$} & & & & & \multirow{4}{*}{8} & \multirow{5}{*}{$\begin{array}{l}\text { - black race, no Japanese ancestry } \\
\text { 口black race \& Japanese ancestry } \\
\text { घblack \& Japanese races } \\
\square \text { Japanese race \& black ancestry } \\
\square \text { Japanese race, no black ancestry }\end{array}$} \\
\hline & & & & & & \\
\hline & & & & 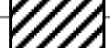 & & \\
\hline & & & 21214 & 21124 & & \\
\hline & 1970 & 1980 & 1990 & 2000 & 2006-2010 ACS & \\
\hline \multicolumn{6}{|l|}{$100 \%$} & \multirow{6}{*}{$\begin{array}{l}\text { black race, no AFKV ancestry } \\
\text { 口black race \& AFKV ancestry } \\
\text { ఐblack \& Asian Ind., Filipino, Korean or Viet. races } \\
\square A F K V \text { race \& black ancestry } \\
\square A F K V \text { race, no black ancestry }\end{array}$} \\
\hline $75 \%$ & & & & & & \\
\hline $50 \%$ & & & & 87 & 811 & \\
\hline \multirow{3}{*}{$\begin{array}{r}25 \% \\
0 \%\end{array}$} & & & 202 & $E$ & & \\
\hline & & & & & & \\
\hline & 1970 & 1980 & 1990 & 2000 & 2006-2010 ACS & \\
\hline
\end{tabular}

continued... 
Figure 2, continued:

Child's Race and Ancestry in Families with Interracially Married Single-Race Householder \& Spouse: Seven types of families with a black parent and a non-black parent in five data sets

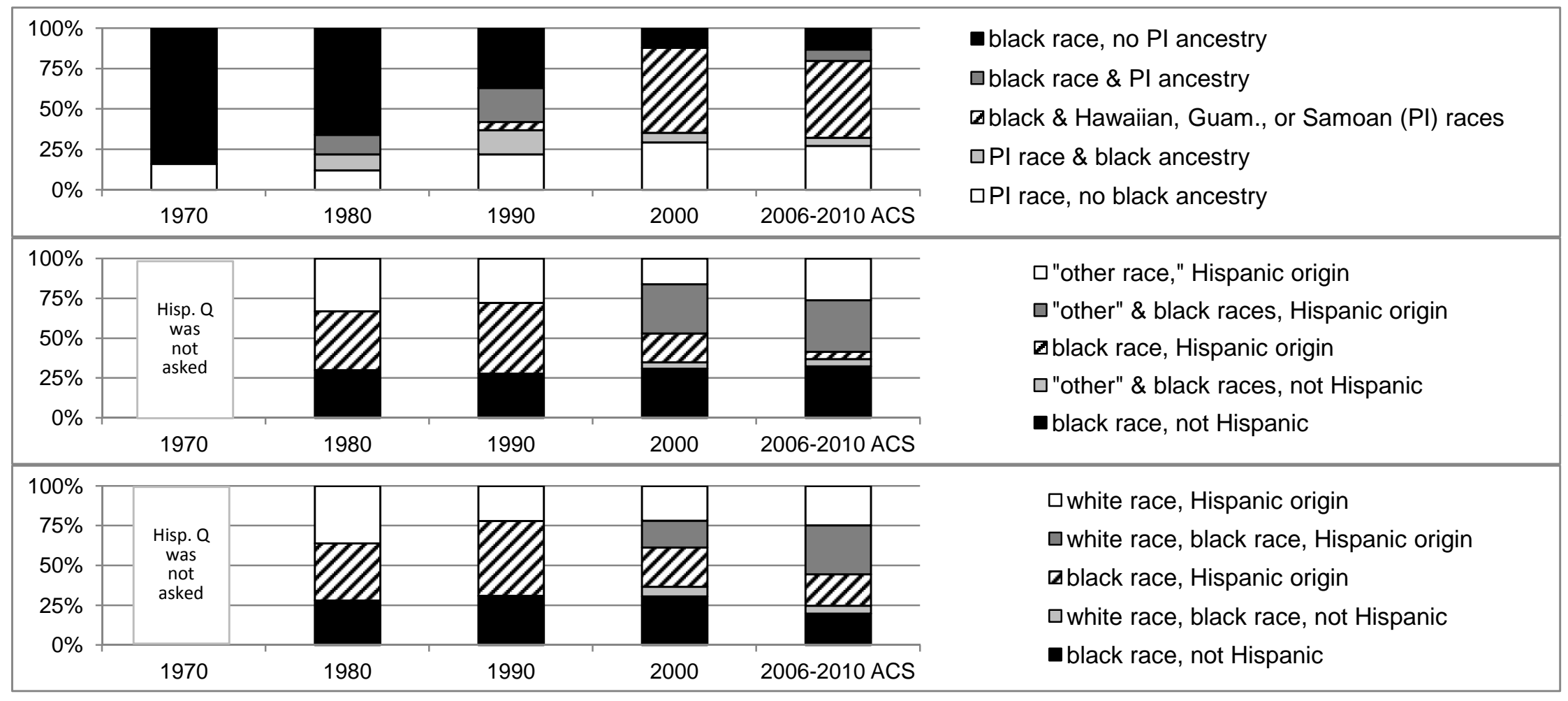

Note: See Table 5 for a numeric version of this information. 
Focus on mixed heritage: Given that all of the children in this study are living with their interracially married parents, we hypothesized that the salience of both parent's races would be high and thus virtually all children would be reported to have both parent's races, regardless of race boundaries. This was not a possibility in 1970, but both race groups could be represented using a combination of the race and ancestry questions in 1980 and 1990; these are shown in rows labeled "white race \& black ancestry" and "black race \& white ancestry." In 2000 and 2006-10, multiple race responses were recorded in the data. Also, in 1990, two-race responses were recorded in the RDC data (unless one of the races was "other"). Mixed heritage responses relevant to this hypothesis are thus in all of the rows for each group except the top and bottom rows (which are labeled, for example, "black race, no white ancestry").

The results in Table 4 and Figure 1 show support for the mixed response hypothesis in the white-Asian groups: a strong majority of the children are described as mixed heritage on the census forms and only about a quarter of these children are presented as monoracial. However, the hypothesis receives less support in other groups. A far smaller proportion of non-Asian children are presented as having mixed heritage. The proportion presented as having mixed heritage is closer to half among all of the other groups of children. In these cases, we are seeing substantial "ethnic attrition" (Duncan and Trejo 2011): interracially married parents are often neglecting to mention one of their children's race/ethnic groups. The groups that are chosen for monoracial identification can be seen as having expansive, permeable boundaries because they can include a first-generation multiracial person.

Group differences: Our second hypothesis is that families with different parent race combinations will show different patterns in how the child's racial heritage is reported. Our related sub-hypotheses can be summarized as follows: (a) non-white parent's race dominates; (b) part-black is presented as all black; (c) indigenous people's sociopolitical motivations encourage monoracial identification; and (d) indigenous people's long history of intermarriage encourages mixed heritage responses. We address each of these in turn. 
The social construction of "white" has historically emphasized whiteness as a pure state any non-white heritage disqualifies a person from claiming whiteness. Thus we predicted that children with a white parent and a non-white parent would tend to be identified with their non-white parent's race. Table 4 and Figure 1 trace this trend over the forty years. In 1970, when reporting mixed heritage was not possible, part-white children were actually more likely to be identified as white than non-white (with the exception of black-white children). This contradicts the hypothesis. As multiple responses have become possible, this pattern has disappeared. Instead, it has become very unlikely that a part-white child would be identified as monoracially white; in most types, only one-sixth to one-tenth of the children are reported to be monoracial whites.

Recalling the social and legal emphasis on hypodecent aimed at American blacks (i.e., the idea that a part-black person is just black), we hypothesized that part-black children are particularly likely to be presented as single-race black and unlikely to be presented as single-race non-black. We find mixed empirical support for both of these expectations. In most years and most family groups in which data are available, double-minority children (Table 5 and Figure 2) are about twice as likely to be reported as monoracially black (e.g., "B race, no AIAN anc") as they are to be reported monoracially non-black (e.g., "AIAN race, no B anc"). This evidence supports our hypothesis. However, the results also show that part-black children are almost universally less likely to be presented as monoracially black than they are to be presented as mixed or non-black.

We consider two hypotheses about the children with an American Indian, Alaska Native, or Pacific Islander parent. First, we note that these indigenous people have political relationships with governments (both tribal and federal) and thus stakes of racial identity are high. We expect that this will push parents out of the middle ground, toward identifying children as all or nothing monoracially indigenous or not indigenous at all. Second, we note that these same groups have been engaging in interracial unions for centuries and are thus quite mixed in terms of their family trees; this could encourage mixed-heritage responses. We find more support for the first of these 
hypotheses than the second, particularly among the part-American Indian/Alaska Native children. Over the forty year period, regardless of the dramatic change in question wording, the percentage of children identified as wholly American Indian/Alaska Native (i.e., no reported white or black ancestry) has remained quite stable - near 30\% among white-AIAN children and near 20\% among black-AIAN children. The proportion identified as mixed has remained relatively low even as the opportunities to report mixed heritage have expanded. White-Pacific Islander children tend to be reported as single race more often than white-Asian children ${ }^{8}$ and thus also lend support to the first of the two hypotheses.

Increase over time: Because of growing social acceptance of interracial unions, as well as an increasingly nuanced public understanding of race, we expected that people of mixed heritage are more likely today than in the past to formally disclose that they are mixed. We expected children of all types of mixed response - whether one race and a different ancestry, or multiple races - to increase their relative share of responses between 1980 and 2010.

In most groups, the percentage of children reported as mixed has increased somewhat over the period. We show the percentage of children reported as either multiple race or mixed race/ancestry in Figure 3 (which is based on Tables 4 and 5). For most groups, the percentage of children reported as mixed increased moderatly from 1980 to 2010, with a consistently higher proportion of part-Asian children reported as mixed in some way. The 1990 to 2000 change in the wording of the race question shifted the specific ways in which families reported their children as mixed, but the race/ancestry combination has also captured many mixed-heritage responses that account for the substantial number of mixed heritage reports in 1980 and 1990. This high level of early mixed heritage reports moderates the overall increase in mixed heritage reports. Note that first generation multiracial American Indian-whites and American Indian-blacks show a decrease in the proportion giving mixed heritage responses.

Distinctive paternal surname: Children in the United States have traditionally been given the last name of their father. In families where the father has a surname that is racially or 
Figure 3: Percent of Children Reported as NOT Monoracial, 1980-2010

\section{Panel A: Mixed heritage responses for children with a white parent}

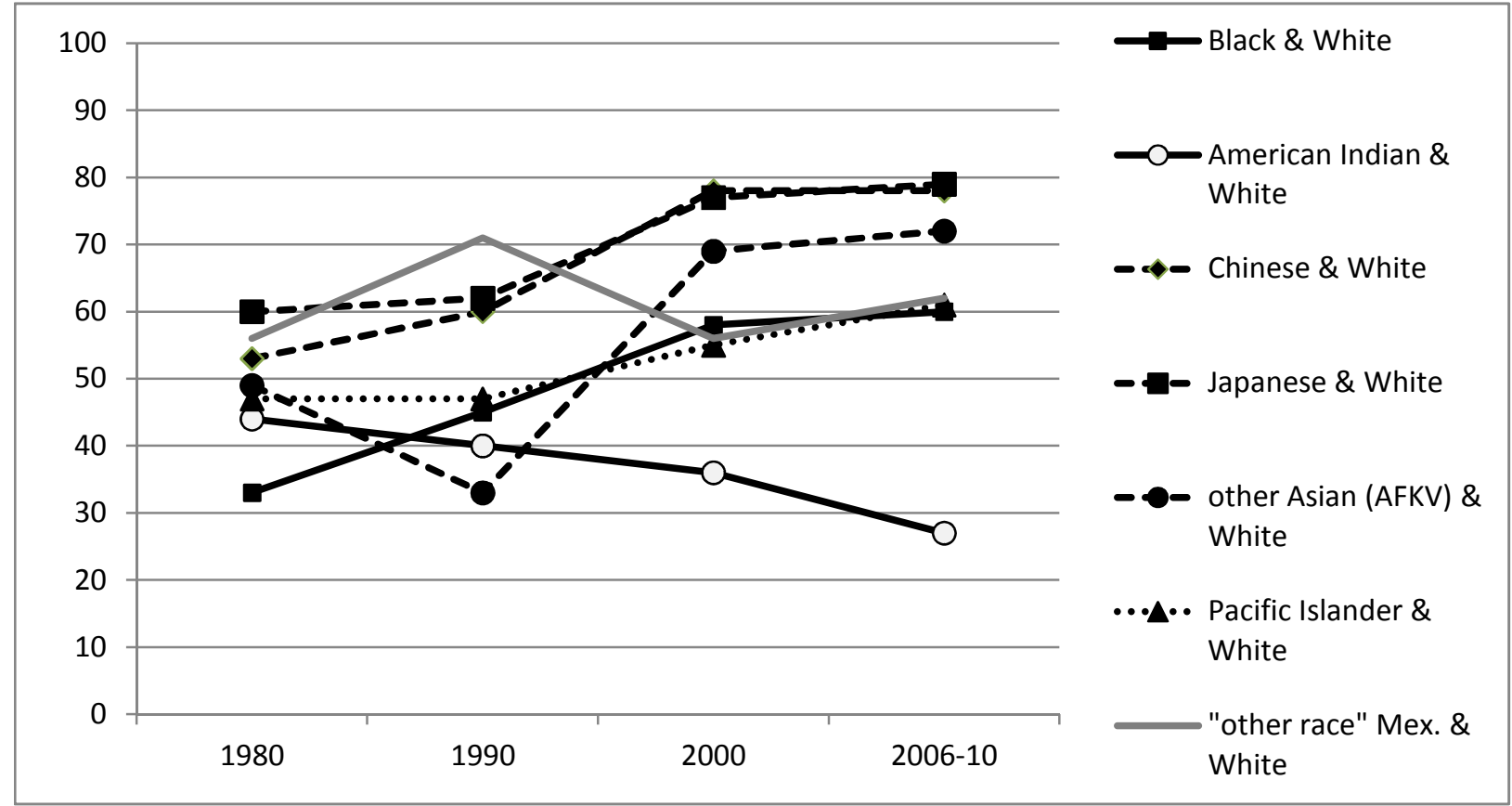

\section{Panel B: Mixed heritage responses for children with a black parent}

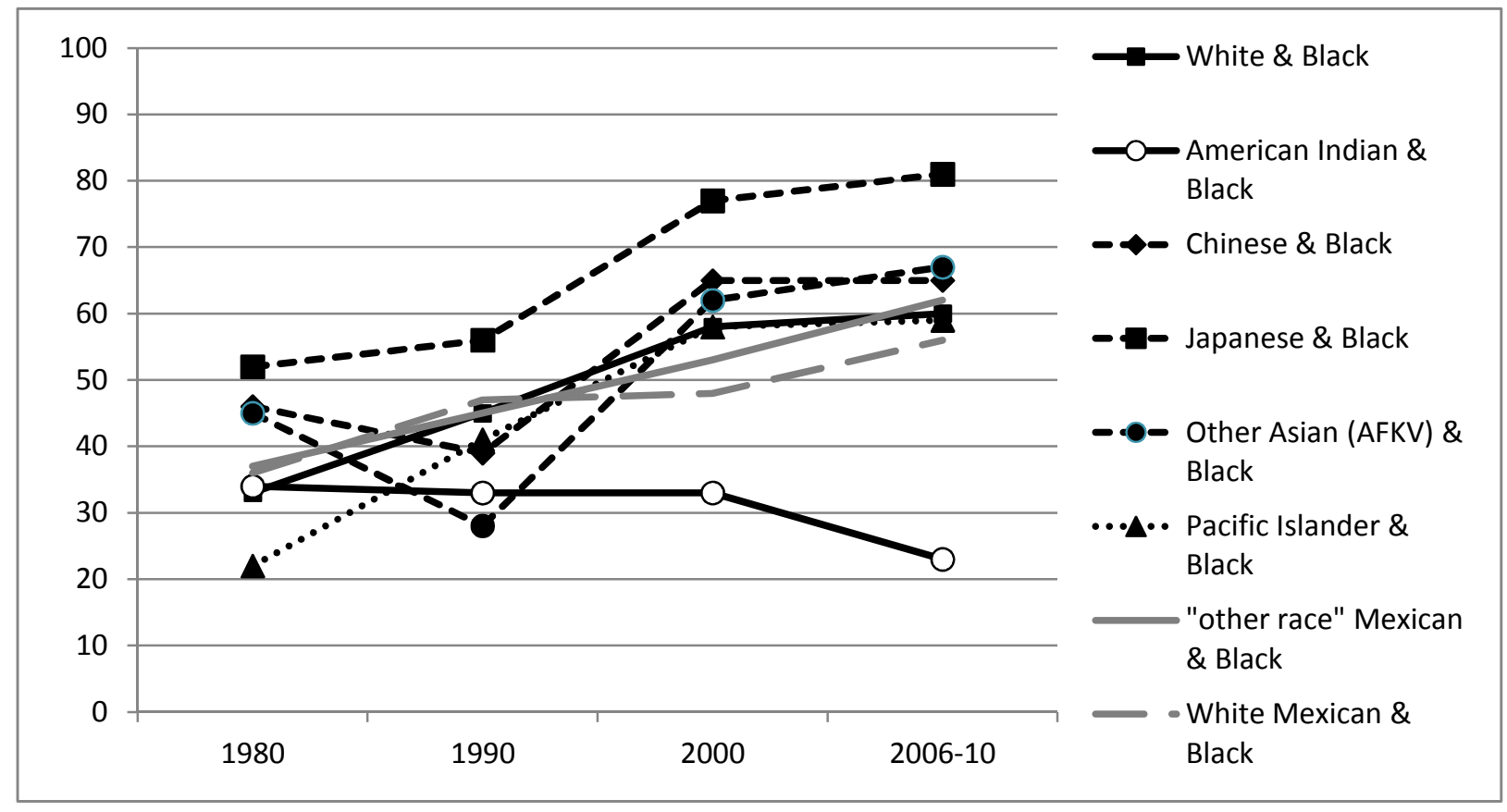

Note: A "mixed heritage" response includes multiple race responses and responses with a race/ancestry combination that mentions both parents' races. See Tables 4 and 5 for numeric versions of this information 
ethnically distinctive - as is often the case with Asian, Pacific Islander, and Mexican names - the child may be more likely to be identified as the same race as the father. In Tables 4 and 5, we present the distribution of child's race/ancestry/origin response separately by parent's race. The available data ${ }^{9}$ show that in every group in every year, an Asian-white, Asian-black, PI-white, or PI-black child was more likely to be reported as racially Asian/PI if his or her father was the Asian or Pacific Islander parent (and perhaps has a distinctive last name) than if his or her father was white or black. This pattern was much stronger in 1970 than in the later years, but has prevailed nevertheless. In families with a Mexican parent, the pattern of tending to follow the father's race is also common (but not universal). In contrast, families in which both parents are white, black, or

American Indian/Alaska Native - groups with a lower predominance of distinctive surnames - do not show the same pattern of identifying the child's race with the father's race. Distinctive last names appear to have some positive effect on the intergenerational transmission of race.

\section{Discussion}

These patterns in children's heritage responses have implications for our hypotheses, relate to previous research, and inform understandings of race group boundaries. In this section, we summarize and contextualize our results.

We find that white-Asian children are especially likely to be reported as mixed heritage, especially multiple race. Bratter (2007) found this pattern using public use data from 2000, but it is unclear why interracially married Asian parents would be particularly likely to report their children as multiple-race. King-O'Riain (2004:180) notes that “Japanese Americans historically did not recognize or accept multiracial individuals as Japanese American" (p.182). It is possible that the communities' emphasis on a monoracial self-perception (also documented by Murphy-Shigematsu 2001 and Spickard 2001) drives people of mixed Japanese-white heritage to notice themselves as different and take on a multiracial identity. 
In contrast to the Asian groups, we find substantial "ethnic attrition" (Duncan and Trejo 2011) among most other types of first-generation multiracial children -- only one racial heritage is reported for many of these children. We find these high rates of single heritage responses surprising given that they are living with parents from two different race groups, and noting the many public figures and interview respondents who emphasize the personal importance of a non-single-race identity. It seems that the public voices do not represent everyone.

In situations where a child of mixed heritage is reported as entirely monoracial, we see this as evidence of a rather weak boundary between the parents' race groups; children of mixed heritage are not strictly excluded from full membership in the group to which they have been assigned. For example, if part-Chinese children were reported as only Chinese (with no non-Chinese ancestry), it indicates that the Chinese race boundary is permeable; claims of Chineseness are not entirely undermined by the presence of non-Chinese heritage.

We interpret our results to indicate that the white race boundary is not very permeable. Most mixed-heritage part-white children are assigned a multiracial or a non-white race response, or at least some non-white ancestry. Few people of mixed heritage are reported as "just white." Whiteness scholars will not be surprised by this result. They find that groups may become socially defined as "white," but until that happens (if ever), its constituents are socially defined as "not white" and claims of whiteness are not accepted.

Prior research on who is considered black has emphasized the persistence of blackness: we also find that there is little ethnic attrition from the black group. We find that part-black children are often reported as having mixed heritage; they are not usually reported as just black. The prior research that highlights the social emphasis on "just black" (e.g., Davis 2001) is focused on the legal and social other view of a part-black person's race. In-home identification is not so simple and thus there is likely a tension in identity that can be revealed by qualitative research (c.f., Rockquemore and Brunsma 2002; Tashiro 2011). 
We find substantially more ethnic attrition among the children of American Indians, Alaska Natives, and Pacific Islanders (as did Bratter (2007) among American Indian/whites). Despite centuries of interracial unions in these groups, their children are especially likely to be reported as monoracial. We hypothesize that this is due to the sociopolitical context - these particular race boundaries are still patrolled by government entities as well as group members with much at stake. The importance of the sociopolitical context illustrates that personal psychology, phenotype, and the family tree are not the only factors that drive race responses.

Our data span four decades. This long-term look at mixed heritage responses reveals that twenty years before multiple race responses were officially allowed, interracially married parents characterized many of their children as having mixed heritage using the ancestry question. We conclude that identification as "mixed" is not simply a response to the new race question and/or recent social movements. Instead, the families' response patterns came first and the new race question followed, decades later. The implementation of the new race question has probably spurred the upward trend in mixed heritage reports, reports that sit outside traditional race boundaries.

We investigated one factor that may be driving some of the variation in race responses distinctive paternal surname. We found that children's race response tends to follow the father in Chinese, Japanese, other Asian, Pacific Islander, and Mexican families, but does not have this tendency in white, black, and American Indian families. This finding justifies further analyses in future research. Multivariate analyses are required to check this result because it could be that the surname effect is driven by another factor. For example, prior research shows that the child's response is likely to match the householder's response so this result could be due to a predominance of father-householder homes in the Asian and Pacific Islander families. Future multivariate analyses should include many other personal, family, and social context factors that have been shown to contribute to or correlate with the heritage reported for (or by) first-generation mixed-race children (Bratter 2007; Campbell 2007; Gullickson and Morning 2010; Jones and 
Smith 2003; Kanaiaupuni and Liebler 2005; Liebler 2010a, 2010b; Qian 2004; Roth 2005; Xie and Goyette 1998).

\section{Implications}

These analyses and results provide leverage on understanding the social construction of race group boundaries in the United States in the past several decades. This information is useful for both race scholars and social demographers. We also note that the ancestry variable provides a very useful expansion of information about the complex phenomena under study.

Relevance for race scholars. When we find ethnic attrition and its opposite in the data, this gives evidence that race group boundaries are permeable; people can and do claim a racial heritage that excludes some groups in their family tree. According to Lee and Bean (2004:223), weak boundaries between race groups imply the declining social significance of race. Our results also indicate that there is considerable room near the edges of race group membership. As Tashiro (2011) recently pointed out, many people of mixed race heritage feel that they are both inside and outside the boundaries of several groups. Other researchers (e.g., Brunsma 2005) have also found wide variation in how people of mixed parentage are racially classified. Our results are consistent with prior research, but stretch the margins of knowledge about the intergenerational transmission of race to additional groups (e.g., double minorities) and back through time. Our study also bolsters the strength of these findings by using the most detailed data and highest density samples that the U.S. Census Bureau can provide.

Relevance to demographic research: The intergenerational transmission of racial identity is a key way in which the size and location of various race populations change over time. The race data presented by the Census Bureau, as well as assessments of race-specific undercount, are affected by the race response choices made by multiracial families. Patterns in the intergenerational transmission of racial identity fundamentally affect the measured sizes of all race groups. Selective ethnic attrition changes the composition of the new generation of race 
incumbents. Demographers working to make race-specific population projections are struggling to incorporate ethnic attrition into demographic models. Health scientists developing race-specific life tables face similar troubles.

Usefulness of the ancestry variable: The 2000 Census and the American Community Survey contain an especially deep well of information about the ways people of mixed heritage see themselves or are seen in their families. These data sets contain the ancestry question, which was introduced in 1980, as well as the new race question. The ancestry question allows researchers to identify people of mixed heritage even if they are not coresiding with their interracially married parents and even if they are among the many who do not report multiple races (see Farley 2004). Thus it represents a vital key to understanding how race group composition is subtly shifting over the generations, and which people are poised at the edges of identification with each group. 


\section{References}

Bauerlein, Mark. 2012. “Elizabeth Warren's Judgment." Chronicle of Higher Education. May 30. http://chronicle.com/blogs/brainstorm/elizabeth-warrens-judgment/47391

Bratter, Jenifer. 2007. "Will 'Multiracial' Survive to the Next Generation? The Racial Classification of Children of Multiracial Parents." Social Forces 86(2):822-849.

Brodkin, Karen. 1998. How Jews Became White Folks: And What That Says About Race in America. Newark: Rutgers University Press.

Brown, J. Scott, Steven Hitlin, and Glen H. Elder Jr. 2007. "The Importance of Being "Other": A Natural Experiment about Lived Race over Time." Social Science Research 36: 159-174

Brunsma, David L. 2005. "Interracial Families and the Racial Identification of Mixed-Race Children: Evidence from the Early Childhood Longitudinal Study." Social Forces 84(2):1131-1157.

Burke, Ruth and Grace Kao. 2011. "Bearing the Burden of Whiteness: The Implications of Racial Self-Identification for Multiracial Adolescents' School Belonging and Academic Achievement." Ethnic and Racial Studies, iFirst Article: 1-27.

Burton, Jonathan, Alita Nandi and Lucinda Platt. 2010. "Measuring Ethnicity: Challenges and Opportunities for Survey Research." Ethnic and Racial Studies 33(8):1332-1349.

Campbell, Mary E. 2007. "Thinking Outside the (Black) Box: Measuring Black and Multiracial Identification on Surveys." Social Science Research 36(3): 921-944.

Cheng, Simon and Kathryn J. Lively. 2009. "Multiracial Self-Identification and Adolescent Outcomes: A Social Psychological Approach to the Marginal Man Theory." Social Forces 88(1): 61-98.

Cornell, Stephen. 1990. "Land, Labor, and Group Formation: Blacks and Indians in the United States." Ethnic and Racial Studies 13(3): 368-388.

Daniel, G. Reginald. 1996. "Black and White Identity in the New Millennium: Unsevering the Ties that Bind." Pp. 121-139 in The Multiracial Experience: Racial Borders as the New Frontier, edited by Maria P. P. Root. Thousand Oaks, CA: Sage.

Davies, Hayley. 2011. "Sharing Surnames: Children, Family and Kinship." Sociology 45(4): 554-569.

Davis, F. James. 2001. Who Is Black? One Nation's Definition. University Park: Penn State University Press.

Duncan, Brian and Stephen J. Trejo. 2011. "Intermarriage and the Intergenerational Transmission of Ethnic Identity and Human Capital for Mexican Americans" Journal of Labor Economics 29(2): 195-227.

Emeka, Amon and Jody Agius Vallejo. 2011. "Non-Hispanics with Latin American Ancestry: Assimilation, Race, and Identity among Latin American Descendants in the US." Social Science Research 40:1547-1563. 
Farley, Reynolds. 2004. "Identifying with Multiple Races: A Social Movement that Succeeded but Failed?" Pp. 123-148 in The Changing Terrain of Race and Ethnicity. Edited by Maria Krysan and Amanda E. Lewis. New York: Russell Sage Foundation.

Ferber, Abby L. 2004. "Defending the Creation of Whiteness: White Supremacy and the Threat of Interracial Sexuality." Pp. 43-58 in The Politics of Multiracialism: Challenging Racial Thinking, Heather M. Dalmage, ed. Albany: State University of New York Press.

Garroutte, Eva Marie. 2003. Real Indians: Identity and the Survival of Native America. Berkeley: University of California Press.

Goldstein, Joshua and Ann Morning. 2000. "The Multiple Race Population of the United States: Issues and Estimates." Proceedings of the National Academy of Sciences 97(11):6230-6235.

Goldstein, Joshua and Ann Morning. 2002. "Back in the Box: The Dilemma of Using Multiple-Race Data for Single-Race Laws." Pp. 119-136 in The New Race Question: How the Census Counts Multiracial Individuals, Joel Perlmann and Mary C. Waters, eds. New York: Russell Sage Foundation.

Gordon, Milton M. 1964. Assimilation in American Life: The Role of Race, Religion, and National Origins. New York, Oxford University Press.

Gullickson, Aaron and Ann Morning. 2010. "Choosing Race: Multiracial Ancestry and Identification." Social Science Research 40(2): 498-512.

Hagan, William T. 1985. "Full Blood, Mixed Blood, Generic, and Ersatz: The Problem of Indian Identity." Arizona and the West 27:309-326.

Hall, Christine C. I. and Trude I. C. Turner. 2001. "The Diversity of Biracial Individuals: Asian-White and Asian-Minority Biracial Identity." Pp. 81-91 in The Sum of Our Parts: Mixed-Heritage Asian Americans, edited by Teresa Williams-León and Cynthia L. Nakashima.

Haney Lopez, Ian F. 2006. White by Law: The Legal Construction of Race. New York: New York University Press.

Harris, David R. and Jerimiah Joseph Sim. 2002. "Who is Multiracial? The Fluidity of Racial Identity among US Adolescents." American Sociological Review 67: 614-627.

Hitlin, Steven, J. Scott Brown and Glen H. Elder, Jr. 2007. "Measuring Latinos: Racial vs. Ethnic Classification and Self-Understandings." Social Forces 86(2):587-611.

Jones, Nicholas A. and Amy Symens Smith. 2003. "New Explorations of Race Reporting for Interracial Couples and Their Children: Census 2000." Paper presented at the Annual Meeting of the Population Association of America, Minneapolis, MN.

Jordan, Winthrop D. 1962. "American Chiaroscuro: The Status and Definition of Mulattoes in the British Colonies." The William and Mary Quarterly 19(2):183-200.

Kanaiaupuni, Shawn Malia and Carolyn A. Liebler. 2005. "Pondering Poi Dog: Place and Racial Identification of Multiracial Native Hawaiians." Ethnic and Racial Studies 28(4):687-721. 
Khanna, Nikki. 2011. "Ethnicity and Race as 'Symbolic': The Use of Ethnic and Racial Symbols in Asserting a Biracial Identity." Ethnic and Racial Studies 34(6): 1049-1067

King-O'Riain, Rebecca Chiyoko. 2004. "Model Majority? The Struggle for Identity among Multiracial Japanese Americans." Pp. 177-192 in The Politics of Multiracialism: Challenging Racial Thinking, Heather M. Dalmage, ed. Albany: State University of New York Press.

Korgen, Kathleen Odell. 1998. From Black to Biracial: Transforming Racial Identity Among Americans. Westport, CT: Praeger.

Lee, Jennifer and Frank D. Bean. 2004. "America's Changing Color Lines: Immigration, Race/Ethnicity, and Multiracial Identification." Annual Review of Sociology 30:221-242.

Lewontin, Richard. 1972. "The Apportionment of Human Diversity." Evolutionary Biology. 6: 391-398.

Lieberson, Stanley. 2000. A Matter of Taste: How Names, Fashions, and Culture Change. New Haven, CT: Yale University Press.

Lieberson, Stanley and Mary C. Waters. 1993. "The Ethnic Responses of Whites: What Causes Their Instability, Simplification, and Inconsistency?" Social Forces 72(2): 421-450.

Liebler, Carolyn A. 2001. Fringes of American Indian Identity. Dissertation (Sociology). University of Wisconsin-Madison.

Liebler, Carolyn A. 2004. "Ties on the Fringes of Identity." Social Science Research. 33/4: 702-723.

Liebler, Carolyn A. 2010a. "Homelands and Indigenous Identities in a Multiracial Era." Social Science Research 39(4): 596-609.

Liebler, Carolyn A. 2010b. "A Group in Flux: Multiracial American Indians and the Social Construction of Race." Pp. 131-144 in Multiracial Americans and Social Class, edited by Kathleen Odell Korgen. NY: Routledge Press.

Liebler, Carolyn A. and Shawn Malia Kanaiaupuni. 2003/4. "Races in the Pacific: Comparisons of Racial Identification among Mixed-Race Native Hawaiians and Other Mixed Race Pacific Islanders." Journal of Intergroup Relations 30(4): 23-48.

Nakashima, Cynthia. 1992. "An Invisible Monster: The Creation and Denial of Mixed Race People in America." Pp. 162-178 in Maria P. P. Root (ed.), Racially Mixed People in America, Newbury Park, CA: Sage.

Nakashima, Daniel A. 2001. "A Rose by Any Other Name: Names, Multiracial/Multiethnic People, and the Politics of Identity." Pp. 111-120 in The Sum of Our Parts: Mixed-Heritage Asian Americans, edited by Teresa Williams-León and Cynthia L. Nakashima.

Omi, Michael and Howard Winant. 1994. Racial Formation in the United States from the 1960s to the 1990s. New York: Routledge.

Painter, Nell Irvin. 2010. The History of White People. New York: W. W. Norton. 
Park, Robert E. 1928 "Human Migration and the Marginal Man." American Journal of Sociology 33: 881-893.

Qian, Zhenchao. 2004. "How Options: Racial/Ethnic Identification of Children of Intermarried Couples." Social Science Quarterly 85(3): 746-766.

Rockquemore, Kerry Ann and David Brunsma. 2002. Beyond Black: Biracial Identity in America. Thousand Oaks, CA: Sage.

Rockquemore Kerry Ann and Laszloffy Tracey A. 2005. Raising Biracial Children. Lanham, MD: AltaMira Press.

Roediger, David R. 2005. Working Toward Whiteness: How America's Immigrants Became White; The Strange Journey from Ellis Island to the Suburbs. New York: Basic Books.

Rohrer, Judy. 2008. "Disrupting the 'Melting Pot': Racial Discourse in Hawai'i and the Naturalization of Haole." Ethnic and Racial Studies 31(6): 1110-1125.

Root, Maria P.P., ed. 1996. The Multiracial Experience: Racial Borders as the New Frontier. Thousand Oaks, CA: Sage.

Roth, Wendy. 2005. "The End of the One-Drop Rule? Labeling of Multiracial Children in Black Intermarriages." Sociological Forum, Vol. 20, No. 1: 35-67.

Ruggles, Steven, J. Trent Alexander, Katie Genadek, Ronald Goeken, Matthew B. Schroeder, and Matthew Sobek. 2010. Integrated Public Use Microdata Series: Version 5.0

[Machine-readable database]. Minneapolis: University of Minnesota.

Russell, Kathy, Midge Wilson, and Ronald Hall. 1992. The Color Complex: The Politics of Skin Color among African Americans. New York: Anchor Books

Smith, William C. 1934. "The Hybrid in Hawaii as a Marginal Man." American Journal of Sociology. 39(4):459-468.

Song, Miri. 2003. Choosing Ethnic Identity. Malden, MA: Blackwell.

Spickard, Paul R. 1991. Mixed Blood: Intermarriage \& Ethnic: Intermarriage And Ethnic Identity In Twentieth Century America. Madison: University of Wisconsin Press.

Spickard, Paul R. 2001. "Who is an Asian? Who is a Pacific Islander? Monoracialism, Multiracial People, and Asian American Communities." Pp. 13-24 in The Sum of Our Parts: Mixed-Heritage Asian Americans, edited by Teresa Williams-León and Cynthia L. Nakashima.

Spickard, Paul R. and Rowena Fong. 1995. "Pacific Islander Americans and Multiethnicity: A Vision of America's Future?" Social Forces 73(4):1365-1383.

Stonequist, Everett V. 1937. The Marginal Man. New York: Charles Scribner's Sons.

Tashiro, Cathy J. 2011. Standing on Both Feet: Voices of Older Mixed Race Americans. Boulder, CO: Paradigm.

U.S. Bureau of the Census. 1976. U.S. Census of Population and Housing: 1970 Procedural 
History PHC(R)-1. Washington, DC.

Waters, Mary C. 1990. Ethnic Options: Choosing Identities in America. Berkeley: University of California Press.

Xie, Yu and Kimberly Goyette. 1998. "The Racial Identification of Biracial Children with One Asian Parent: Evidence from the 1990 Census." Social Forces 76(2):547-70. 


\section{Notes}

${ }^{1}$ Some people of mixed heritage will report themselves as single race, just as some people of mixed ancestry will report only a subset of their ancestries (Lieberson and Waters 1993). We use the terms "single race" and "multiple race" in reference to the person's response to the race question, with no claim about their family tree or what they mean by "race."

${ }^{2}$ It is not known who provided the responses for the child, but in our samples a parent is listed as the householder and we expect that the person filling out the form would be likely to claim householder (or householder's spouse) for themselves. If this is the case, one of the parents of the child being studied would have filled out the form.

${ }^{3}$ The finding that there is more genetic variation within each "race" than there is between the races was first published by Lewontin in 1972. However, the Census Bureau recognized race as non-scientific even in the 1970s: "The concept of race as used by the Bureau of the Census does not denote any scientific definition of biological stock" (U.S. Bureau of the Census 1976:15-9).

${ }^{4}$ The only currently available data for 1960 is a one-percent public-use sample. It is not suitable for this study because there are too few cases to generate reliable estimates.

${ }^{5}$ Our sample sizes would be severely reduced if limited to young people and would not achieve the size needed for disclosure from the RDC. Children ages 18 and older make up 28 to 34 percent of people living with their interracially married parents (one of whom is a householder) in public-use versions of each data set (from http://usa.ipums.org/usal, Ruggles et al. 2010). Supplementary analyses of the RDC data show that our results would not be affected by restricting our analyses to children under age 18 but we note that older children tend toward monoracial responses.

${ }^{6}$ We consider the child's Hispanic origin only in cases where he or she has a Mexican Hispanic origin parent. To improve the interpretability of our results, we do not combine all 
Hispanic origin parents but instead focus on the two largest groups: Mexican origin whites and Mexican origin "other race" parents.

${ }^{7}$ All percentages are weighted to represent the US population of the time.

${ }^{8}$ Asians and Pacific Islanders share a similar place in the U.S. racial landscape, but the Asian groups have lower rates of intermarriage with whites and a shorter history of intermarriage with whites.

${ }^{9}$ Among double-minority families shown in Table 5, the data are sparse due to marriage norms and practices (e.g., there are few families with a Chinese father and a black mother) and an Asian or Pacific Islander race with black ancestry is rarely reported. When necessary to protect respondent confidentiality, we exclude this category from the column percentages and/or suppress parent-specific information. 